\title{
Analysis of Problems and Opportunities Faced by Heilongjiang Province in Economic Development
}

\author{
Lingyan Li \\ College of Economics and Business administration of Heihe University, Heihe Heilongjiang, \\ 164300, China
}

Key words: Heilongjiang Province, Economic development, Regional coordination.

\begin{abstract}
Since China implemented revival strategy for old industrial bases in the northeast region in 2003, economic development of Heilongjiang Province has been greatly adjusted and improved. With economic development, domestic and overseas development environments faced by Heilongjiang Province change. In the process of economic development and transformation, new problems are encountered, such as "superimposed three periods", difficult structure transformation of economic development, insufficient development power of regional coordination and linkage, and serious development situation of trading with Russia. Meanwhile, Heilongjiang Province is also faced with the opportunities of strong support of new national policy and improved international environment. In the face of problems and opportunities, Heilongjiang Province should seize the policy opportunity, actively develop border port cities, highlight the development advantage of border port cities trading with Russia and actively drive all-round transformation and development of economy in Heilongjiang Province.
\end{abstract}

\section{Introduction}

Since China implemented revival strategy for old industrial bases in the northeast region in 2003, economic development of Heilongjiang Province has been greatly adjusted and improved. With economic development, domestic and overseas development environments faced by Heilongjiang Province change. In the process of economic development and transformation, Heilongjiang Province encounters new problems and challenges.

\section{Problems faced by Heilongjiang Province in economic development}

Firstly, similar to other regions in China, Heilongjiang Province is also faced with "superimposed three periods".

Since China implemented revival strategy for old industrial bases in the northeast region, economy of Heilongjiang Province has gained leap-type development. In economic development process, Heilongjiang Province is also faced with "superimposed three periods": shift period of economic growth rate, throe period of structural adjustment and digestion period of stimulus policy.

The following table reflects the change in total output value of Heilongjiang Province in 2003-2015. We can see from the table that after the revitalization from 2003 to 2012, GDP of Heilongjiang Province increased by 2.2 times, and the income of urban and rural residents also increased by a large margin. But as nationwide economic development stage changed in 2013, economic growth rate of Heilongjiang Province slowed down, and economic down pressure of Heilongjiang Province increased. GDP growth rate suddenly decreased. According to data of National Bureau of Statistics, economic growth rate of Heilongjiang Province decreased by 5.7\% in 2015, and GDP growth rate was much lower than nationwide GDP growth rate. 


\begin{tabular}{|c|c|}
\hline Year & Heilongjiang Province \\
\hline 2003 & 4430.00 \\
\hline 2004 & 5303.00 \\
\hline 2005 & 5513.70 \\
\hline 2006 & 6211.80 \\
\hline 2007 & 7104.00 \\
\hline 2008 & 8314.37 \\
\hline 2009 & 8587.00 \\
\hline 2010 & 10368.60 \\
\hline 2011 & 12582.00 \\
\hline 2012 & 13691.58 \\
\hline 2013 & 14382.9 \\
\hline 2014 & 15039.4 \\
\hline 2015 & 15083.7 \\
\hline
\end{tabular}

Table 1. Total output value of Heilongjiang Province in 2003-2015 (Unit: 100 million Yuan)

Data source: Statistical Yearbook of China (2004-2015), website of National Bureau of Statistics: http://www.stats.gov.cn/tjsj/

The problems and difficulties faced by Heilongjiang Province in economic structural adjustment are more severe. Firstly, Heilongjiang Province as an industrial base in the initial stage of establishment of China has unbalanced industrial structure all the time. Energy economy and manufacturing industry occupy a large proportion in the whole economic structure, while the development of light industry and service industry is weak in Heilongjiang Province. Secondly, in economic development of Heilongjiang Province, private economy occupies a small proportion. Due to the influence of industrial structure, state-owned economy in Heilongjiang Province still occupies the dominant position. Thirdly, adjustment of industrial structure, unemployment in cities and towns, system transformation and laborers' wage level cause that labor participation rate in Heilongjiang Province is the minimum nationwide. In Heilongjiang Province, there were 528,000 laid-off workers in state-owned enterprises, accounting for nearly $10 \%$ nationwide in 1998. In 2014, the average wage of employees in cities and towns of Heilongjiang Province was 44036 Yuan, lower than nationwide average level 56360 Yuan. In nationwide ranking, Heilongjiang Province was last but one.

During the ten years of revitalization of the northeast China, structural imbalance is accompanied with rapid economic development of northeast. Among the three sectors driving economic growth, investment outshines others, and its contribution rate to economy exceeds $60 \%$. In the resources of finance and tax, real estate industry is dominant. Stimulus policy represented by huge investment and implemented to cope with financial crisis in 2008 inevitably brought about three problems. Firstly, economic growth potential was used excessively in advance, and future development space was squeezed. Thus, disorderly resource development and serious environmental destruction were caused. Secondly, production capacity fell sharply, and excess production capacity problem became more prominent. Thirdly, overall debt ratio increased fast in a short time, and obvious economic bubbles was directly caused.

Secondly, the previous economic development advantage has become the shortcoming of current economic development.

Although slow economic development of Heilongjiang Province is inevitably influenced by macroeconomic environment, many problems left by Heilongjiang Province in the development process seriously hinder its rapid development. Petroleum, timber, coal and grain which once played an important role in economic development has become negative pulling force of economic development in Heilongjiang Province. Due to exploitation and extensive use for many years, the reserve of petroleum, coal, ferrous metal and other resources reduces. Resource exhaustion and the rise in exploitation cost make raw material industry of Heilongjiang Province based on these resources increasingly caught in the plight. Some resource-based cities are also faced with resource exhaustion problem, which results in insufficient city development power. Heilongjiang Province is 
the most important grain storage of China. However, agricultural development of Heilongjiang Province has the following problems for a long time: insufficient input, backward farmland infrastructure, and poor anti-risk capability of agriculture. Industrial structure adjustment of Heilongjiang Province remains further optimizing, and the system and mechanism need to reform and innovation. At present, except petroleum and gas exploitation, petroleum processing industry and ferrous metal smelting \& processing in Heilongjiang Province, market share of other industries is below $10 \%$. The market of many traditional superior products increasingly shirks due to low competitiveness. Industrial development of Heilongjiang Province also lacks vigor. Management of state-owned enterprises is relatively rigid, and there is short of innovation impetus.

Thirdly, the power of regional harmonious and interactive development is insufficient.

Since geographic position of various regions in Heilongjiang Province is adjacent, they own the common history and cultural background as well as similar and consistent resource endowment, industrial feature and industry structure. Besides, region and infrastructure are integral. The similar resource structure and arrangement played a great role for economic start and development. But in current economic development process, strong regional competitiveness appears in order to respective economic development just because of such similarity and consistency. In development planning and plan arrangement, various regions lack coordination and cooperation and even blind competitions are caused. Thus, internal poisoning of the whole region is unclear, and the mechanism of labor division and cooperation is weak. Thus, serious losses of energy and resource are caused. In recent years, harmonious development speed of Heilongjiang Province is still slow. The causes for insufficient power for harmonious and interactive development mainly include the following aspects. On the one hand, the influence of administrative system on economy is still large. The industrial system of Heilongjiang Province which was formed in the period of planned economy causes that large enterprises in this region are mainly state-owned enterprises. These enterprises also have many administration traces in operation and management. Administration-oriented investment and development make enterprise operation not guided by the market. Meanwhile, the contradiction between administrative division and economic division is often exposed to each region when their respective interests get involved. Thus, some regions hinder entire economic fusion and connection in order to protect their own interests. On the other hand, market economization degree of Heilongjiang Province is relatively low. Some existing system and laws are not sound and perfect enough, which to some extent hinders enthusiasm and feasibility of each province and region for interactive economic development. Currently, regional cooperation of Heilongjiang Province advances smoothly. Material breakthrough has not been achieved to certain degree.

Fourthly, development situation of trading with Russia is severe.

Heilongjiang Province is adjacent to Russia, so it frequently trades with Russia. As Chaongjitu Development and Opening Up Pilot Zone in Jilin Province, and development and opening up of northeast part of Inner Mongolia and border region in Heilongjiang Province ascended to national strategy in 2009 and 2013 respectively, Heilongjiang Province is positioned to an important window of opening up to Northeast Asia especially in the strategy of "the Belt \& Road". Chaongjitu Development and Opening Up Pilot Zone is the core area of Northeast Asia region. Hence, a new opportunity comes for foreign trade development of Heilongjiang Province. But as the influence of western countries on economic sanctions of Russia deepens, economy of Russia suffers serious influence. Meanwhile, the situation of Heilongjiang Province's trading with Russia is also severe. According to statistics of customs, import and export volume of China with Russia was RMB 422.73 billion in 2015, down $27.8 \%$ compared with the last year. This figure accounted for $1.7 \%$ of total export and import volume of China in 2015. Export volume to Russia was RMB 216.23 billion, down 34.4\%. Import volume from Russia was RMB 206.5 billion, down 19.1\%. Accumulative favorable balance of trade was RMB 9.73 billion. Heilongjiang Province ranked the second place in terms of trading with Russia. Heilongjiang Province achieved USD 10.85 billion trading volume with Russia, down $53.4 \%$ year on year. This figure accounted for $51.7 \%$ of total export-import volume in the whole province, and $16 \%$ of total volume of trading with Russia nationwide. 


\section{Opportunities faced by Heilongjiang Province in economic development}

Firstly, national policy gives strong support.

In December 2008, Heilongjiang Province issued Development Planning of Border Opening Up Belt in Heilongjiang Province. In August 2013, the State Council officially approved Border Development and Opening Up Planning of Heilongjiang and Northeast Part of Inner Mongolia, and border development and opening up of northeast part of Inner Mongolia and Heilongjiang Province ascended to national strategy. In September and October 2013, State President Xi Jinping proposed the significant initiative of co-building "Silk Road Economic Belt" and "the 21st Century Maritime Silk Road" during visiting countries in Central Asia and Southeast Asia. In the strategic conception of |the Belt \& Road”, he proposed to improve Heilongjiang-Russia railway and regional railway network, enhance joint rail and water transportation cooperation with Heilongjiang, Jilin, Liaoning and far east area of Russia, drive construction of Beijing-Moscow Eurasian high-speed transportation corridor and construct an important window for opening up to the north. The state points out new path and direction for economic development of Heilongjiang Province and offers beneficial policy support and guarantee.

Secondly, international environment improves greatly.

Since China implemented revival strategy for old industrial bases in the northeast region in 2003, economic development of Heilongjiang Province has been greatly adjusted and improved. With economic development, domestic and overseas development environments faced by Heilongjiang Province change. Seeing from external environment, Russia continuously enhances development of far east area, and the attitude becomes increasingly positive. On February 26, 2014, Sino-Russian Tongjiang Railway Bridge came into building. The history that there is no river-crossing railway bridge between China and Russia will end, and another international combined transportation channel between China's northeast railway network and Russia's Siberian railway forms. Besides, more beneficial conditions and platforms are offered for opening up of Heilongjiang Province.

\section{Countermeasures and suggestions}

Firstly, seize the policy opportunity and actively develop border port cities

In recent national development strategies, Heilongjiang Province has gained unprecedented opportunities. For Heilongjiang Province, the pace of development and opening up in border area will speed up, and opening up level will improve. Main border port cities of Heilongjiang Province will gain new breakthroughs in economic development with the help of development and opening up strategy, become new economic development zone in Heilongjiang Province and finally drive nationwide coordinated regional development. Heilongjiang Province should seize the opportunity, develop rapidly and focus on development and opening up. Border port cities will become the key point of development and opening up. Development and opening up of border port cities should be based on self-development. Opening up should serve as the leader driving economic development of border area. Main border port cities should serve as the point of strength for regional development. The border port cities should highlight their respective advantages and have distinct characteristics. In opening up, they should cooperate with each other and carry out differential development. All-round opening up of Heilongjiang Province can be really achieved only when border port cities are arranged overall as a whole and carry out interactive development. Thus, under the arrangement of national strategy, interactive development of main border port cities in Heilongjiang Province becomes an inevitable requirement for opening up.

Secondly, highlight advantages of border port cities in development with Russia

Border port cities in development with Russia are in the forefront of opening up to Russia. But in the past development process, unclear development positioning and non-prominent development characteristics existed. Besides, competitions were more than cooperation due to position and resource similarity. Thus, interactive development of border port cities in development with Russia 
contributes to Heilongjiang Province to give play to regional comparison advantage, improve technological progress and independent innovation ability, and drive regional economic growth. Meanwhile, it has very important significance for Heilongjiang Province to become an important hub of opening to Russian and Northeast Asia and important economic growth region in the border.

\section{Acknowledgments}

This paper is a planned project of philosophy and social science research of Heilongjiang Province "Study on Interactive Development of Main Border Port Cities in Heilongjiang Province”, Project No.: $14 \mathrm{C} 037$.

\section{References}

[1] Ma Youjun, Zhang Mei, Enlightenment of Shanghai Free Trade Zone building on border development and opening up in Heilongjiang Province. Fendou, 2014.(1):39-40

[2] Zhang Xiaolian, Seizing national strategy opportunity to drive leapfrog development of border development and opening up in Heilongjiang Province. Study \& Exploration, 2014.(7):1-3 